\title{
Auscultation While Standing
}

\author{
Michael E. Jobansen, MD, MS, Associate Editor \\ Samantha N. Wu, MD, Grant Family Medicine, ObioHealth \\ Ann Fam Med 2017;15(6):iii. https://doi.org/10.1370/afm.2167.
}

The Annals of Family Medicine encourages readers to develop a learning community to improve health care and health through enhanced primary care. Participate by conducting a RADICAL journal club. RADICAL stands for Read, Ask, Discuss, Inquire, Collaborate, Act, and Learn. We encourage diverse participants to thinking critically about important issues affecting primary care and act on those discussions. ${ }^{1}$

\section{HOW IT WORKS}

In each issue, the Annals selects an article and provides discussion tips and questions. Take a RADICAL approach to these materials and post a summary of your conversation in our online discussion. (Open the article and click on "TRACK Discussion/ Submit a comment.") Discussion questions and information are online at: http://www.annfammed.org/site/AJC/.

\section{CURRENT SELECTION}

Lefort B, Cheyssac $E$, Soulé N, et al. Auscultation while standing: a basic and reliable method to rule out a pathological heart murmer in children. Ann Fam Med. 2017;15(6):523-528.

\section{Discussion Tips}

Evaluations of diagnostic tests are a critical, but underappreciated, proportion of the medical literature. In clinical practice, appropriate use of high value diagnostic tests (eg, Lachman's test for ACL tear) ${ }^{2}$ and avoidance of low value tests (eg, Homan's sign for deep vein thrombosis, ${ }^{3}$ Tinel or Phalen signs for carpal tunnel in patients with symptoms $)^{4}$ has the potential to improve the quality and value of medical care.

\section{Discussion Questions}

- What is a diagnostic test? Why do they matter? Are questions you ask patients diagnostic tests?

- What question is asked by this study and why does it matter?

- How does this study advance beyond previous research and clinical practice on this topic?

- How strong is the study design for answering the question?
-What are positive and negative predictive values? What are sensitivity and specificity? How are these statistics used to judge diagnostic tests?

- What is a likelihood ratio and how is it calculated? Are you able to calculate likelihood ratios from this study? If so, does this diagnostic test have a strong impact on the probability of the diagnosis?

- What is a Fagan's nomogram and how is it used? ${ }^{5}$

- What are the main study findings?

- To what degree could the findings be affected by:

- How patients were selected or excluded?

- How the main variables were measured?

- Chance?

- How comparable is the study sample to similar patients in your practice? How transportable are the findings?

- What is spectrum bias? How could it apply to this study?

- How might this study change your practice? Education? Research?

- Are further studies on the topic warranted? If so, how would you design the study?

- Could different diagnostic tests combine to further improve decision making in applicable clinical scenarios?

\section{References}

1. Stange KC, Miller WL, McLellan LA, et al. Annals Journal Club: It's time to get RADICAL. Ann Fam Med. 2006;4(3):196-197. http:// annfammed.org/cgi/content/full/4/3/196.

2. Knee ligaments and menisci. In: Simel DL, Rennie D. eds. The Rational Clinical Examination: Evidence-Based Clinical Diagnosis. New York, NY: McGraw-Hill; 2009. http://jamaevidence.mhmedical.com/content. aspx?bookid=845\&sectionid $=61357572$. Accessed Oct 17, 2017.

3. Deep vein thrombosis. In: Simel DL, Rennie D. eds. The Rational Clinical Examination: Evidence-Based Clinical Diagnosis. New York, NY: McGraw-Hill; 2009. http://jamaevidence.mhmedical.com/content. aspx?bookid $=845$ Esectionid $=61357505$. Accessed Oct 13, 2017.

4. Carpal tunnel syndrome. In: Simel DL, Rennie D. eds. The Rational Clinical Examination: Evidence-Based Clinical Diagnosis. New York, NY: McGraw-Hill; 2009. http://jamaevidence.mhmedical.com/content. aspx?bookid=845\&sectionid=61357497. Accessed Oct 13, 2017.

5. Fagan TJ. Letter: Nomogram for Bayes theorem. N Engl J Med. 1975;293(5):257. 